\title{
VARIABLE INTEREST ENTITY STRUCTURE AS A FORM OF INVESTMENT UNDERTAKEN BY CHINESE COMPANIES ON FOREIGN STOCK EXCHANGES
}

\section{Sylwia Cieślik*}

\begin{abstract}
The aim of the article: The purpose of this article is to discuss theoretical issues concerning the nature of the Variable Interest Entity (VIE) structure and to analyze the scale and functioning of companies using this structure to issue securities on foreign exchanges. The main research hypothesis was that the VIE structure is widely used by Chinese companies to issue securities on international stock exchanges.

Methodology: The basis of the research material are academic articles, reports of institutions and corporations, journal articles and other sources, as well as statistical data of companies collected on stock exchanges. Through analysis of stock market data, the authors sought to identify the number of companies operating under the VIE structure and determine the amount of capital invested on the largest international stock exchanges.

Results of the research: Empirical research indicates that the VIE structure is used by Chinese companies operating in sectors of the Chinese economy restricted by the authorities in order to issue securities, and thus raise the necessary capital for further development. The results indicate the large amount of accumulated capital, the huge number of entities involved in their operation, as well as the high risk associated with the investment.
\end{abstract}

Keywords: Variable Interest Entity structure, international capital market, China, investments, stock ex-change, investment risk.

JEL Class: F30, F31, G31, G32.

"MA, Faculty of Economics and Sociology, University of Lodz, e-mail: ssylwia.cieslik@gmail.com. 


\section{INTRODUCTION}

Variable Interest Entity (VIE) is an organizational structure based on a number of relations between various economic entities, whose functioning depends on the realization of certain economic goals (Whitehill, 2017: 3-4). Therefore, the VIE is an investment structure where a Chinese operating company is controlled by an offshore entity, on the basis of a number of agreements (Latham \& Waltkins, 2019: 3) that allow the related entities to obtain a certain level of control over certain companies, without the need to directly hold shares, as well as a significant shareholding in those companies (Guo, 2014: 1).

The idea of establishing a VIE structure is closely related to the political and economic situation of the People's Republic of China (PRC) (FTSE Russell, 2018: 5). The VIE is a recognized and widely used business structure in the entire foreign investment sector, under the supervision of the authorities in the PRC, in particular in the technology, telecommunications and media sector. Foreign direct investment (FDI) undertaken by foreign entities is a desired effect by the authorities, however, due to the politically sensitive nature of certain sectors of the economy, such investments are subject to special surveillance. This applies primarily to: banking, press releases, TV broadcasters, wholesale and retail, mining, agriculture, utilities, telecommunications, Internet, energy and technology (Shi, 2011: 1267-1268). Companies operating in the sectors listed in the Catalog for Guidance of Foreign Investment Industries, which seek the possibility to issue securities on foreign exchanges are required to obtain permission from the State Council of the PRC, the highest Chinese executive body (Schindelheim, 2012: 220-222). Obtaining such a permit is complicated and timeconsuming, therefore companies have tried to bypass the restrictions established by the authorities in this area. To this end, a VIE structure was created, which can be called a quiet compromise between the Chinese authorities control over strategic economic sectors and the development of private enterprises (Whitehill, 2017: 3).

The growing significance of the VIE structure for Chinese companies as one of the forms of financing which has led to their enormous growth, is shown in statistics. In 2000, only $1 \%$ of all Chinese private companies issued securities on Chinese stock exchanges (Gilli, 2019: 1), while in 2017, over 150 companies using VIE structure, went public on American stock exchanges (Whitehill, 2017: 6). It is noted that at the end of 2017, the stock market capitalization of Chinese companies registered in the Cayman Islands, which operated under the VIE structure, was $\$ 1.7$ trillion, of which $\$ 747$ billion corresponded to shares listed on the NYSE and NASDAQ (Powell, 2019).

The aim of the article is to discuss theoretical issues concerning the essence of the VIE structure and to analyze the scale and functioning of companies using 
this structure to issue securities on foreign stock exchanges. The choice of the topic was dictated primarily by the virtual absence of the VIE structure issue in the literature, as well as the lack of its comprehensive and interdisciplinary presentation in foreign literature.

The main research hypothesis is that the VIE structure is widely used by Chinese companies to issue securities on international stock exchanges. The multidimensional nature of this issue requires a strong move beyond the economic sciences and a more complete context, using different fields of knowledge.

Empirical research was conducted by analyzing stock exchange reports containing companies listed in October 2020, annual reports of companies, as well as the report of the U.S.-China Economic and Security Review Commission, containing the list of Chinese companies listed on the largest U.S. stock exchanges on October 2, 2020. The research material is based on academic articles, reports from institutions and corporations, articles from journals and other sources, as well as company statistics gathered on stock exchanges.

\section{ANALYSIS OF THE VIE STRUCTURE}

A typical VIE structure is divided into two segments - one with domestic ownership and the other with foreign investments. The activities that are carried out within the sector reserved by Chinese regulations are located in the VIE entity, while the entity that is admitted to foreign investments is set in the Chinese branch of the operating company, i.e. Wholly Foreign Owned Entity (WFOE). The offshore company, the issuer of securities, owns the WFOE (Gillis, 2014: 62-63). Taking into account the above, there are three main entities within this structure offshore, i.e. the foreign holding company, WFOE, as well as the Operating Company, also called VIE.

\subsection{Entities constituing the VIE structure}

Analysing this structure, the significance of foreign investors, i.e. natural or legal persons from whom the capital comes, should also be underlined. These entities purchase securities from the offshore company, registered in the so-called tax haven (Brown, 2017: 203). The most popular places of registration of such companies are Cayman Islands, British Virgin Islands and the United States (Gillis, 2019: 4). A holding company is also called offshore, because this entity usually does not carry out any activity and its main function consists in figuring on foreign stock exchanges. Therefore, the offshore unit cannot be controlled by the Chinese authorities due to its operation outside China (Guo, 2014: 577). 
The establishment of the VIE structure also involves the registration of an indirect company, usually based in Hong Kong, which is wholly owned by an offshore company that acts as an entry point into China and as a legal buffer, i.e. an additional collateral in the established structure (Brown, 2017: 204). However, the establishment of this entity is not obligatory, and the main purpose of establishing these companies is to minimize tax deductions on dividends paid from China (Gillis, 2019: 3-4).

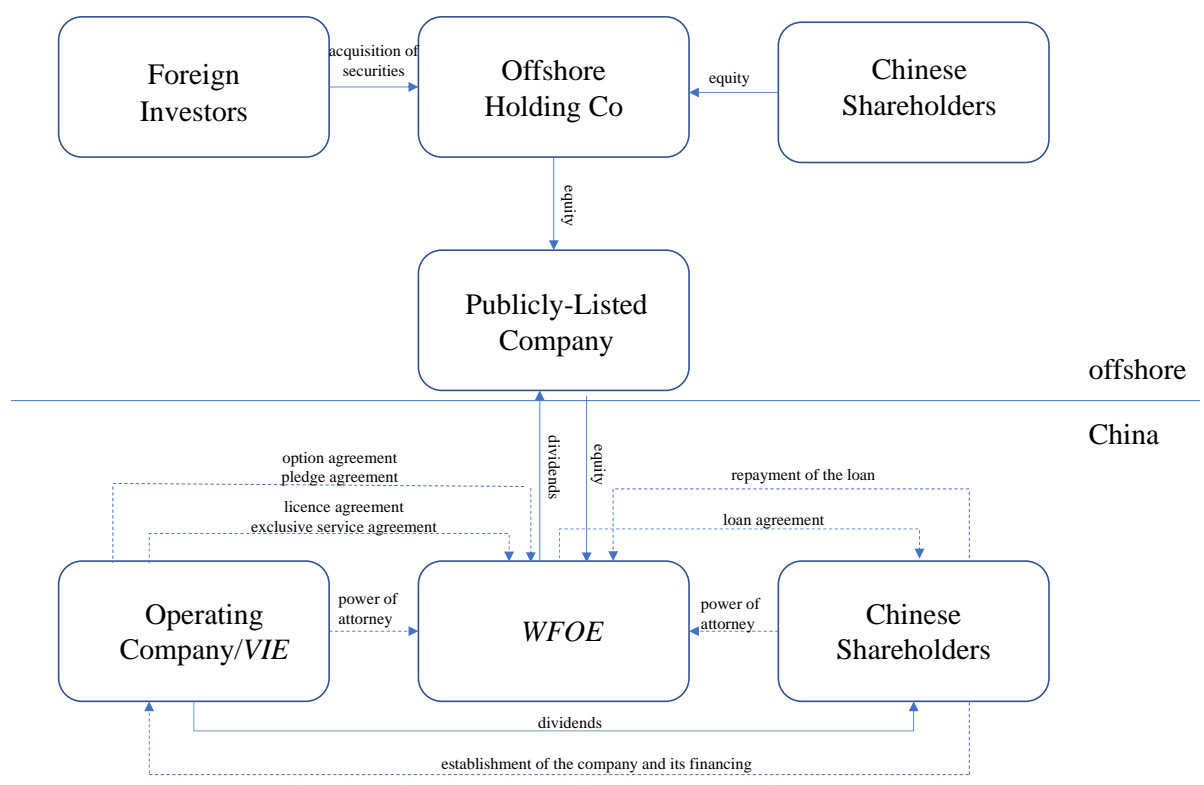

Figure 1. The Variable Interest Entity structure diagram

Source: own study based on Shen, 2012: 930-932 and Whitehill, 2017: 4-6.

Establishing the next of these entities, the WFOE unit is often used by multinational companies to open the way to doing business in China (Gillis, 2019: 3-4). Despite foreign capital, this entity can operate in the territory of the PRC, because it is not a direct beneficiary of the license granted by the Chinese authorities to operate in the protected sector (Coppola et al., 2020: 22). However, this does not mean that the activity of WFOE is not regulated by the Chinese authorities - because of the foreign capital, this entity has to face a lot of regulations and restrictions on its operation in the territory of PRC (Gillis, 2019: 3). In order to solve the problem of obtaining a license to operate in the reserved sector, an operating company is established, which is owned exclusively by Chinese citizens (Larson, 2019: 210). Between the WFOE, the operating 
company and the Chinese shareholders, agreements are concluded whose main purpose is to transfer voting rights and profits to a listed company, i.e. offshore (Brown, 2017: 204-205). A further reason for concluding such sets of bilateral agreements is also the possibility for the offshore company to represent itself before foreign investors that it owns the operating company for international accounting and reporting purposes (Coppola et al., 2020: 45).

The VIE, also known as an operating company (Whitehill, 2017: 4), is an entity whose founder and owner is a person of Chinese nationality, usually a reliable employee (Guo, 2014: 578). By the fact that the VIE is owned by a Chinese citizen, it can be argued that the entity is a national property with the right to apply for a permit to operate in a sector subject to certain restrictions. Thus, there is a duality of arguments for the use of this structure - it is possible to reassure foreign investors that they buy the company's securities to encourage them to invest their capital, and at the same time, in order to apply for a license to operate in the restricted sector, it is possible to declare to Chinese regulators that this entity is fully owned by Chinese citizens (Coppola et al., 2020: 21). The activity of the VIE, on the other hand, is largely regulated by Chinese regulations requiring it to undertake only licensed activities (Schindelheim, 2012: 203).

\subsection{Identification of connections established between the entities}

The relationships between the entities comprising the VIE structure are based on shareholding relationships, as well as on legal relationships that are established under concluded legal agreements (Brown, 2017: 203-205). The ownership relations are marked in Figure 1 with continuous lines, while those based on legal relations are marked with dotted lines. The Chinese shareholders have ownership interests in a domestic operating company as well as the holding company operating outside the PRC. The second group of investors - foreign investors, thanks to the invested capital, hold securities of the offshore company. The offshore company, on the other hand, is owned by a WFOE company operating in China. Analyzing the second type of relations, i.e. legal relations, two groups of agreements should be distinguished. The first one is a series of legal agreements concluded between Chinese shareholders and the WFOE company, which are primarily aimed at exercising the rights of Chinese shareholders in voting on company matters. The second group of agreements are concluded between the domestic operating company and the WFOE, under which the WFOE is obligated to provide the operating company with business services and the operating company is obliged to provide remuneration due to the WFOE (Shen, 2012: 930-932). 
However, it is indicated in the literature that in reality, the provision of these services is a sham and the conclusion of these agreements is only intended to transfer capital from abroad to China (Larson, 2019: 210). In this structure, the links between the above mentioned entities are most unclear (Coppola et al., 2020: 22). The agreements concluded between the WFOE, Chinese shareholders and the operating company are only intended to mimic the ownership of the capital for the regulatory authority to recognize the operating company as Chinese property. The VIE structure operates in such a way that the WFOE provides Chinese owners with a zero-interest loan, which is secured by the owners' equity. In addition, the Chinese shareholders grant the WFOE an exclusive option to purchase the company at a predetermined price, which can be confirmed by proxy agreements. The relationships resulting from these agreements give the Chinese shareholders control of the operating company that imitates the control of their equity interests. Moreover, in order to transfer the profits of the operating company to WFOE, an exclusive agreement is concluded, in which the operating company employs WFOE to provide technical services such as website maintenance, programming, sales support, implementation services, learning program development, etc., while WFOE charges a fee for providing these services, which is approximately equal to the total profit of the operating company (Coppola et al., 2020: 22).

Undoubtedly, it is also worth noting the scheme involving the flow of capital between the entities comprising the VIE structure. First of all, the operating company, which benefits from its activities, transfers its profits to the WFOE in the form of payment for the services provided by this entity (Shen, 2012: 931), based on a number of contractual arrangements which aim at absorbing all profits made and transferring them in the form of a commercial transaction. Then, after the WFOE distributes the dividend, a part of the profits is transferred to the offshore. If there is another subsidiary in the VIE structure, the dividend is also distributed with its participation (Brown, 2017: 205).

It should also be noted that basing the whole structure on contracts binding entities from different countries and not on the ownership shares held, indicates its fragility and high risk associated with investing in these entities. However, the conclusion of these contracts is crucial for the functioning of the VIE structure and also confirms its originality. Thanks to these contracts Chinese owners can maintain actual control over the ownership and management of the operating company. These agreements also allow the offshore company to consolidate its financial statements, as well as to participate in the economic profits and losses of the operating company. These features are key to an offshore company's future listing on the international stock exchange and to achieving tax efficiency in crossborder transactions (Lee, 2011). 


\section{METHODOLOGY AND DATA}

The purpose of this study is an attempt to identify a number of Chinese companies operating in the sectors controlled by the PRC authorities, operating on the basis of the VIE structure, and to determine the amount of capital they have invested on the largest international stock exchanges in terms of turnover, i.e.: NYSE (New York Stock Exchange), NASDAQ, AMEX (American Stock Exchange), LSE (The London Stock Exchange), DAX (Frankfurt Stock Exchange), and SEHK (The Stock Exchange of Hong Kong Limited). The analysis was performed on selected markets of the previously mentioned exchanges.

The data on companies was collected through the analysis of stock exchange reports, containing the list of companies of October 2020, annual reports of companies, as well as the report of the U.S.-China Economic and Security Review Commission, containing the list of Chinese companies listed on the largest American stock exchanges on October 2, 2020. The data from the above mentioned documents was narrowed down, which was based on several assumptions. First of all, companies that made an IPO after 2000, i.e. the year when the VIE structure started to be used, were analysed. Secondly, the sector in which the company operates was examined and compared with the reserved sectors listed in the Catalogue of Guidelines for foreign investment sectors. Thirdly, the study examined only companies that are headquartered in China and issue shares. Fourthly, information on the use of the VIE structure in the most recently published annual reports of companies was considered in the establishment of the list of companies. Fifthly, the national-level Chinese stateowned enterprises (SOEs) were not taken into consideration. In other words, it was considered that if a company from the private sector is located in China, operates in one of the reserved sectors, and issues shares after 2000, the information about operating on the basis of the VIE structure is additionally included in its most recently published annual report that the company operates using the VIE structure.

However, the limitations of this study should be also considered. Due to many uncertainties related to the legality of the structure itself and ownership relations, it is difficult to collect data on all companies on the basis of stock exchange reports, prospectuses or other sources. It should be added that the place of registration as well as the name of the company itself may not indicate the existence of links with Chinese entities. In addition, companies may conceal from their stakeholders the fact that they are making an investment, around which there is much controversy and doubt. Considering the aforementioned, this study is merely an attempt to estimate the size of the capital and the number of these companies on selected stock exchanges. 


\section{RESULTS}

While attempting to identify the number of companies operating under the VIE structure, a geographical distinction by world region was used by considering the largest stock exchanges in North America, Europe and Asia. Companies from selected stock exchanges were analyzed in terms of the sector of operation, the time of the first issued securities on a given stock exchange (IPO), as well as the market capitalization.

\subsection{North America}

Based on the report prepared by the U.S. and Chinese Economic and Security Review Committee from October 2, 2020, as indicated in Table 1, 193 Chinese companies using the VIE structure were listed on the three largest American stock exchanges - NASDAQ, NYSE and AMEX. Recent research indicates that in 2018, the share of Chinese NASDAQ listed companies that used the VIE structure increased from $53 \%$ to $92 \%$ in seven years, and over the same period, the share of companies operating under the VIE structure on the New York Stock Exchange increased from $29 \%$ to $64 \%$ (Liu, 2018).

Table 1. List of Chinese companies listed on American stock exchanges (i.e. NYSE, NASDAQ and AMEX) in October 2020 using Variable Interest Entity structure

\begin{tabular}{|l|c|c|}
\hline \multicolumn{1}{|c|}{ Sector } & $\begin{array}{c}\text { Number of } \\
\text { companies }\end{array}$ & Market Capitalization (mln USD) \\
\hline Technology & 59 & 183,552 \\
\hline Finance & 41 & 11,956 \\
\hline Consumer's services & 30 & 243,372 \\
\hline Consumer's goods & 24 & 111,096 \\
\hline Health care & 15 & 23,439 \\
\hline Business services & 9 & 947,307 \\
\hline Industry & 9 & 2,156 \\
\hline Energy & 2 & 682 \\
\hline Real estate & 2 & 68,019 \\
\hline Media & 1 & 312 \\
\hline Transport & 1 & 24,676 \\
\hline Total & $\mathbf{1 9 3}$ & $\mathbf{1 , 6 1 6 , 5 6 7}$ \\
\hline
\end{tabular}

Source: own study based on U.S.-China Economic and Security Review Commission 2020. 
The total stock market capitalization of the Chinese companies listed on American stock exchanges is USD 1.6 trillion. All the companies, presented in Table 1, operate in reserved sectors. Based on own calculations, which were carried out on the basis of the aforementioned report limited to companies using the VIE structure, the largest number of companies (more than 50\% of all analyzed entities) conduct business activity in the finance and technology sector (see Chart 1).

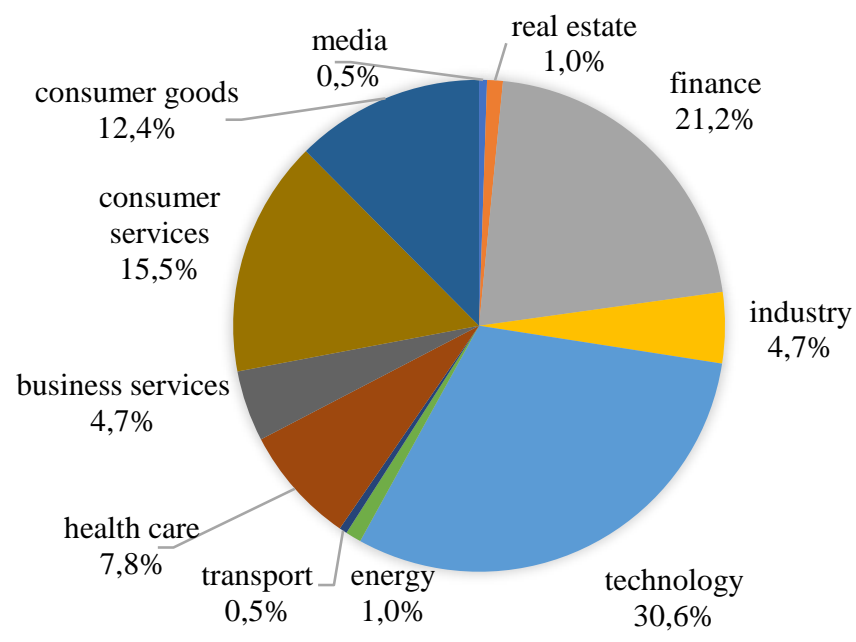

Chart 1. Overview of companies using the Variable Interest Entity structure listed on American stock exchanges (i.e. NYSE, NASDAQ and AMEX) on October 2, 2020 by sectors of operation

Source: own study based on U.S.-China Economic and Security Review Commission 2020.

Analysing companies by their market value, most of them are relatively small investments $-84 \%$ of companies have capitalization up to $\$ 5$ billion (see Chart 2). It should be noted that despite many reservations about the legality of the VIE structure, in recent years more and more companies have decided to use it. Notwithstanding signals from the PRC authorities expressing their disapproval of the use of this structure, this has not resulted in a decrease in interest of Chinese companies in issuing securities. Admittedly, until 2009, a much smaller number of companies decided to invest on American stock exchanges, but a significant increase in the number of companies listed on American stock exchanges has been observed since 2014 (see Chart 3). 


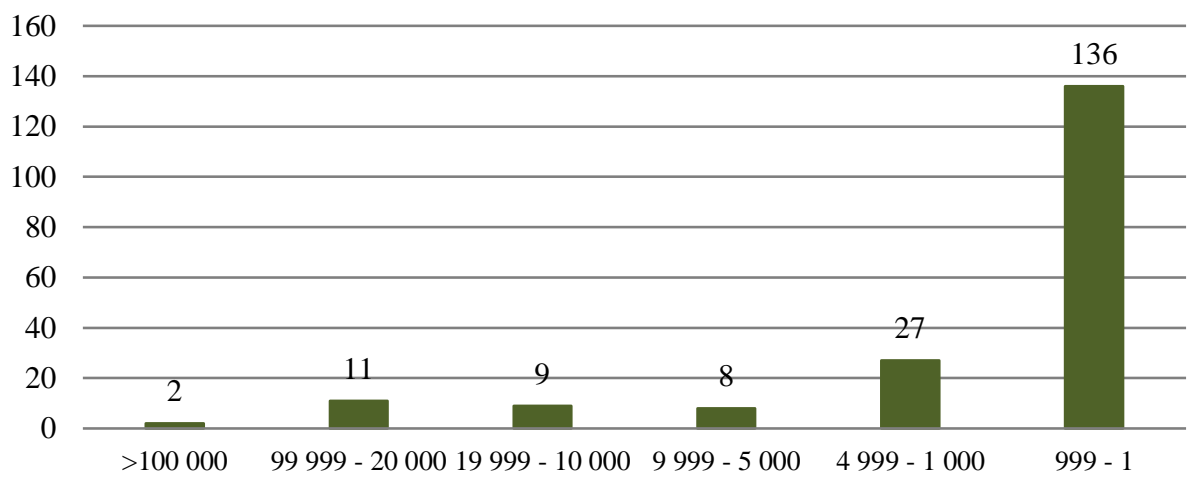

Chart 2. Overview of Chinese companies using the Variable Interest Entity structure listed on American stock exchanges (i.e. NYSE, NASDAQ and AMEX) on October 2, 2020 according to the market capitalization (mln USD)

Source: own study based on U.S.-China Economic and Security Review Commission 2020.

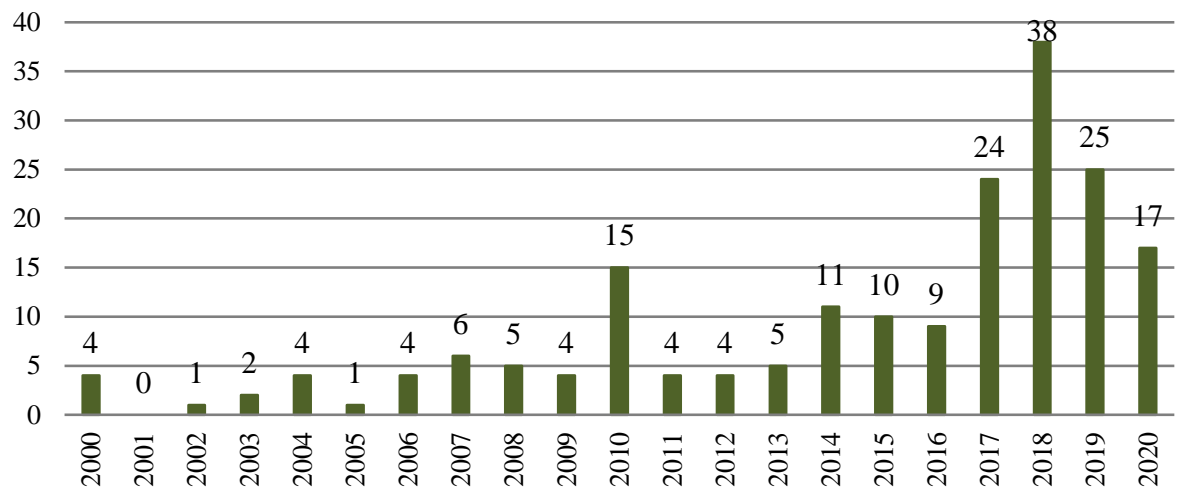

Chart 3. Overview of Chinese companies using the Variable Interest Entity structure listed on American stock exchanges (i.e. NYSE, NASDAQ and AMEX) on October 2, 2020 by IPO date

Source: own study based on U.S.-China Economic and Security Review Commission 2020.

In addition, the Council of Institutional Investors made a significant observation from the point of view of making investments by foreign investors. Based on its 2017 survey, less than 1/5 of companies listed on American stock exchanges operating under the VIE structure paid or expected to pay dividends to shareholders (Whitehill, 2017: 12). Such conduct of Chinese companies only 
leaves investors the possibility to rely on the appreciation of the company's share price to obtain a return on investment. As the authors of the study indicate, behind the non-payment of dividends there may be the conviction of Chinese companies that the capital accumulated in China should remain in China.

\subsection{Europe}

The analysis of companies using the VIE structure on the European continent was conducted on the two largest stock exchanges in terms of capitalization, i.e. the London Stock Exchange and the Frankfurt Stock Exchange. Tables 2 and 3 list the companies listed on these exchanges.

Table 2. Chinese companies using the Variable Interest Entity structure listed on the Main Market and AIM in October 2020 on LSE

\begin{tabular}{|c|c|c|c|c|}
\hline No. & The company & $\begin{array}{l}\text { Market capitalization } \\
(\mathrm{mln} \text { GBP })\end{array}$ & $\begin{array}{l}\text { IPO } \\
\text { year }\end{array}$ & Sector \\
\hline 1 & $\begin{array}{l}\text { Fidelity China Spec. } \\
\text { Situation PLC }\end{array}$ & $1,943.3$ & 2010 & finance \\
\hline 2 & $\begin{array}{l}\text { JPMORGAN European } \\
\text { Invest TST PLC }\end{array}$ & 213.87 & 2006 & finance \\
\hline 3 & $\begin{array}{l}\text { Adamas Finance Asia } \\
\text { Limited }\end{array}$ & 22.48 & 2014 & finance \\
\hline 4 & $\begin{array}{l}\text { Fastforward Innovations } \\
\text { Limited }\end{array}$ & 13.14 & 2006 & finance \\
\hline 5 & $\begin{array}{l}\text { Hutchison China } \\
\text { MediTech Limited }\end{array}$ & $3,427.14$ & 2006 & health care \\
\hline 6 & $\begin{array}{l}\text { Univision Engineering } \\
\text { Limited }\end{array}$ & 4.22 & 2005 & energy \\
\hline 7 & Walcom Group Limited & 0,19 & 2006 & $\begin{array}{l}\text { consument's } \\
\text { services }\end{array}$ \\
\hline 8 & $\begin{array}{l}\text { China Yangtze Power } \\
\text { Co. Ltd. }\end{array}$ & 4.33 & 2020 & energy \\
\hline 9 & $\begin{array}{l}\text { SDIC Power Holdings } \\
\text { Co. Ltd. }\end{array}$ & 0.08 & 2020 & energy \\
\hline & Total & $5,628.75$ & & \\
\hline
\end{tabular}

Source: own study based on London Stock Exchange (a) 2020 and London Stock Exchange (b) 2020 . 
Table 3. Chinese companies using the Variable Interest Entity structure listed on the markets: Prime Standard, General Standard and Scale in October 2020 on DAX

\begin{tabular}{|c|l|c|c|l|}
\hline No. & \multicolumn{1}{|c|}{ The company } & Market capitalization $(\mathrm{mln} €)$ & $\begin{array}{c}\text { IPO } \\
\text { year }\end{array}$ & \multicolumn{1}{|c|}{ Sector } \\
\hline 1 & Haier Smart Home Co. & 5,950 & 2018 & $\begin{array}{l}\text { consument's } \\
\text { services }\end{array}$ \\
\hline 2 & Roy Asset HLDG & 13.15 & 2015 & industry \\
\hline 3 & $\begin{array}{l}\text { United Power } \\
\text { Technology AG }\end{array}$ & 0.39 & 2011 & industry \\
\hline 4 & $\begin{array}{l}\text { Zhongde Waste } \\
\text { Technology }\end{array}$ & 0.77 & 2007 & industry \\
\hline & Total & $\mathbf{5 , 9 6 4 . 3 1}$ & & \\
\hline
\end{tabular}

Source: own study based on Deutsche Börse Cash Market 2020.

Comparing the presence of Chinese companies on stock exchanges in different parts of the world to European stock exchanges, it should be noted that investments of Chinese companies in Europe are not as popular as e.g. in America or Hong Kong. There are nine Chinese companies that have decided to issue securities on Europe's largest stock exchange, the LSE, and they use the VIE structure for this purpose (see Table 2). Most of them operate in the financial and energy sectors. The total capitalisation of these companies is over $£ 5.5$ trillion. The majority of them decided to issue securities before the financial crisis of 2007.

According to the list of Chinese companies operating on DAX, only four of them use the VIE structure for this purpose (see Table 3). Companies operating in the industry and consumer services sector are characterised by relatively low capitalization - nearly 6 trillion EUR.

\subsection{Asia}

A lot of Chinese companies issue their securities on the Hong Kong Stock Exchange. Hong Kong, even though it is part of the PRC, is characterized by many legal and political system differences, which are due to the long period of separation of this territory from the rest of China. Due to the lack of many restrictions in this part of the country, the SEHK is a place where many Chinese companies decide to issue their securities. The currency in this region of China is the Hong Kong dollar (HKD) (Charltons, 2014: 2). 
Table 4. Overview of Chinese companies using Variable Interest Entity structure listed in the SEHK in October 2020

\begin{tabular}{|l|c|c|}
\hline \multicolumn{1}{|c|}{ Sector } & $\begin{array}{c}\text { Number of } \\
\text { companies }\end{array}$ & Market capitalization (mln HKD) \\
\hline Finance & 72 & $3,642,208$ \\
\hline Transport & 38 & 466,194 \\
\hline Industry & 34 & 335,649 \\
\hline Technology & 34 & 376,904 \\
\hline Energy & 25 & 125,609 \\
\hline Health care & 19 & 213,007 \\
\hline Consument's services & 10 & 235,705 \\
\hline Business services & 8 & 48,165 \\
\hline Media & 3 & 2,139 \\
\hline Public utility & 3 & 1,441 \\
\hline Consumer goods & 2 & 1,024 \\
\hline Total & $\mathbf{2 4 8}$ & $\mathbf{5 , 4 4 8 , 0 4 5}$ \\
\hline
\end{tabular}

Source: own study based on Hong Kong Exchanges and Clearing Limited 2020.

In October 2020, the SEHK listed 248 Chinese companies outside the administrative territory of Hong Kong. The total capitalization of Chinese companies using the VIE structure on the two main segments of this stock exchange, i.e. the Main Market and GEM (Growth Enterprise Market) was nearly HKD 5.5 trillion (see Table 4). The largest number of companies, nearly $50 \%$ of Chinese companies, are those operating in the finance and transport sector (see Chart 4). The large percentage were also companies from the industry, energy and technology sectors.

Considering the size of the companies' capitalization, a significant part of them is characterized by a relatively low stock market value (less than HKD $1 \mathrm{bln})$. However, it can be noted that compared to companies issuing securities on U.S. and European stock exchanges, the Hong Kong Stock Exchange has the highest percentage of Chinese companies with a stock market capitalization of more than HKD 5 bln (see Chart 5). This can be justified by geographical proximity and the greater confidence of Chinese companies in making investments within their own territory. 


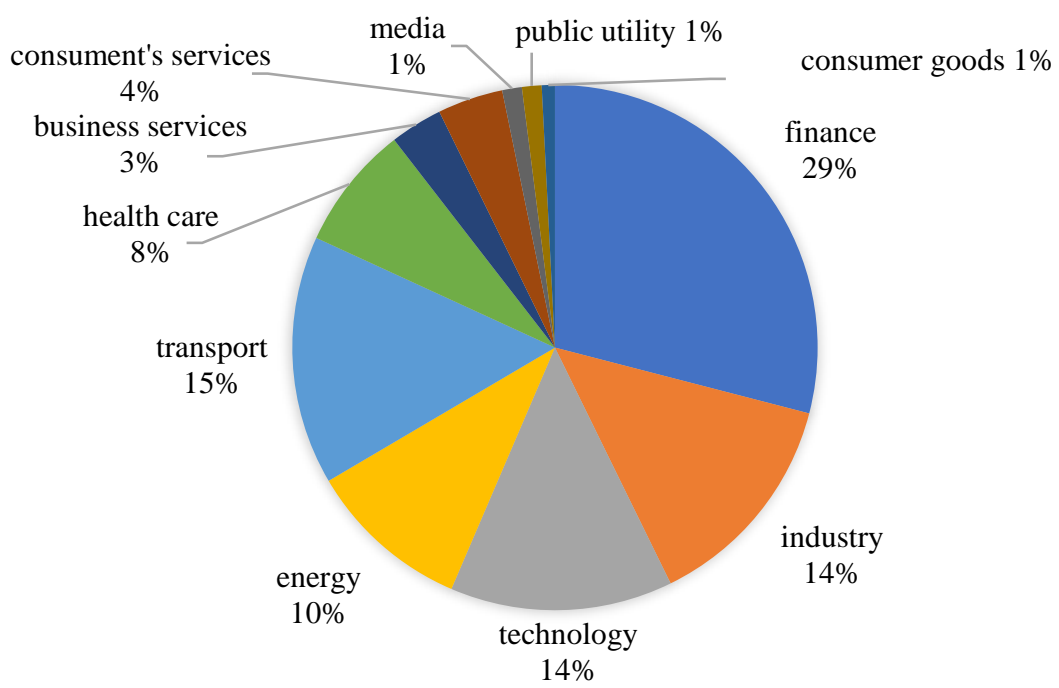

Chart 4. Chinese companies using the Variable Interest Entity structure listed on October 31, 2020 in SEHK by industry sector

Source: own study based on Hong Kong Exchanges and Clearing Limited 2020.

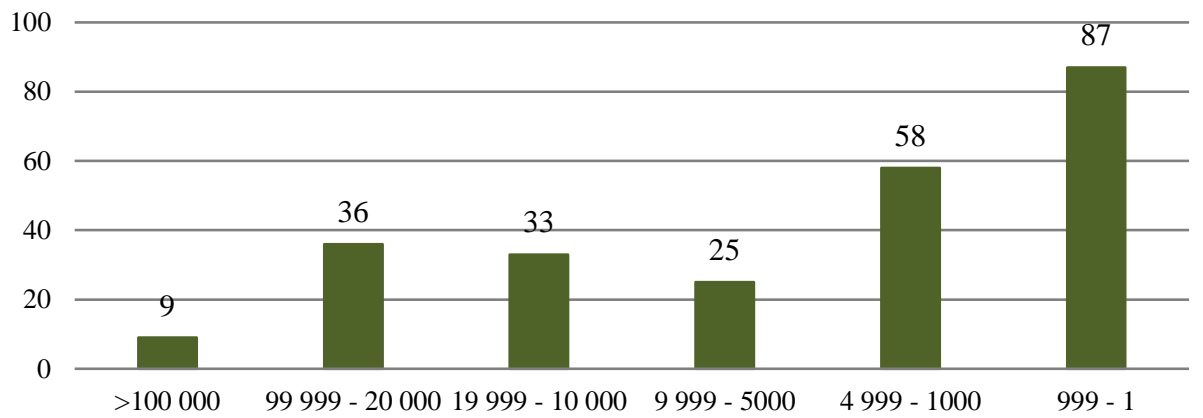

Chart 5. Number of companies using the Variable Interest Entity structure listed on the Hong Kong Stock Exchange on October 31, 2020 by market capitalization (bln HKD)

Source: own study based on Hong Kong Exchanges and Clearing Limited 2020. 


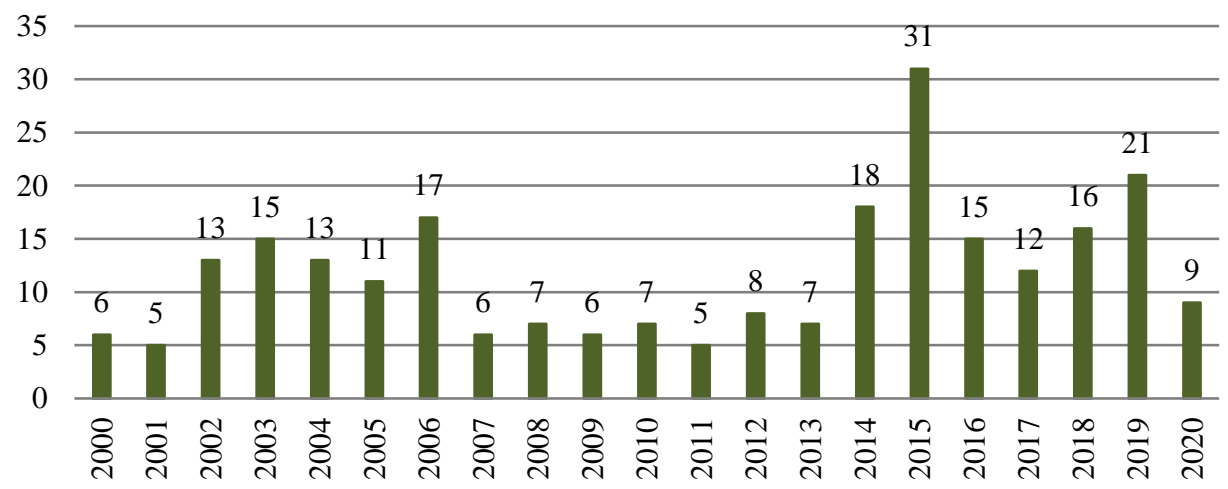

Chart 6. Number of companies using the Variable Interest Entity structure listed on the Hong Kong Stock Exchange on October 31, 2020 by IPO date

Source: own study based on Hong Kong Exchanges and Clearing Limited 2020.

Similarly, to the American and European stock exchanges, most Chinese companies have been investing on the Hong Kong Stock Exchange since 2014 (see Chart 6). The chart above illustrates the relationship between Chinese companies investing on international stock exchanges and the financial crisis of 2007. The companies' increased activity in 2002-2006, i.e., the period from the widespread use of this structure among Chinese companies to the beginning of the financial crisis, as well as the period from 2007-2013, when the number of IPOs on the Hong Kong Stock Exchange decreased. This dependence was certainly caused by companies' scepticism about the possibility of recording a positive return on investment. The years 2014-2019 show another wave of growing interest of Chinese companies on international stock exchanges. In 2020, nine IPOs were recorded on the Hong Kong Stock Exchange, which should be explained by the COVID-19 pandemic.

\section{CONCLUSIONS}

The VIE structure is one example that highlights the opportunities offered by the Chinese political system to domestic and foreign entities, as well as revealing numerous risks that are the consequence of operating not within the bounds, but within the limits, of the law. As a potential, what should be pointed out is the large amount of foreign capital raised by these companies and the possibility of foreign expansion of these companies. The research indicates that Chinese companies are mainly listed on the American and Hong Kong stock exchanges, simultaneously underlying their expansion in Europe. 
Among the risks associated with the application of this structure, it is worth emphasising the situation of foreign investors, who are exposed to high risks of non-enforcement of their rights. According to experts, only a few investors are aware of the risk associated with investing in companies operating under this structure (Gillis, 2019: 6-7). It was noted that the 99\% of individual investors are not aware of the risk of investing in these companies and also institutional investors, especially those who are not sufficiently familiar with the Chinese market, do not understand the fragility of the structure on which these companies are based (Liu, 2018). Moreover, it should be indicated that the actual amount of securities issued by companies operating under the VIE structure is very difficult to estimate. Despite the use of VIEs in their structure, companies often do not include such information in financial statements or prospectuses.

Further development of the VIE structure is difficult to predict. However, it seems that the most acceptable scenario is the legalization of this structure or the abolition of the Chinese authorities' restrictions on foreign investment by companies in the reserved sectors. It seems highly improbable to directly prohibit the application of this structure or to sanction entities for using it, because of the enormous financial benefits that Chinese companies receive. The silent consent of the Chinese authorities allows economic operators to break the rules adopted so far and take advantage of the opportunities that can result in very successful financial results. Taking into account China's aspirations to achieve a dominant position in the world economy and the importance of the VIE structure itself for both Chinese economic entities and foreign investors, the activity of Chinese companies in the international capital market is certainly one of the most interesting issues related to investing.

\section{REFERENCES}

Brown, I.E. (2017). China's leaked CSRC report five years later: Baseline for VIE trajectory? Houston Journal of International Law, 39(1), pp. 197-236.

Charltons, (2014). Listing PRC Companies in Hong Kong Using VIE Structures, https://www.charltonslaw.com/legal/ipo/Listing-PRC-companies-in-Hong-Kong-using-VIE-structures.pdf [Accessed 31.10.2020].

Coppola, A., Maggiori, M., Neiman, B. and Schreger, J. (2020). Redrawing the Map of Global Capital Flows: The Role of Cross-Border Financing and Tax Havens. Becker Friedman Institute, International Economic Initiative. Working Paper 2019-118, pp. 1-54.

Deutsche Börse Cash Market (2020). Listed companies in Prime Standard, General Standard and Scale, https://www.deutsche-boerse-cash-market.com/dbcm-en/instruments-statistics/statistics/ listes- companies [Accessed 31.10.2020].

FTSE Russell (2018, September 1). Understanding China's Economic and Market Developments: Managing China's Transition Into Global Benchmarks, https://content.ftserussell.com/sites/default/files/research/ftse-russell_understanding-china_s-economic-and-market-developments_september-2018_docx.pdf. 
Gillis, P.L. (2014). Son of Enron: Investors Weigh the Risks of Chinese Variable Interest Entities. Journal of applied Corporate Finance, 26(3), pp. 61-66.

Gills, P.L. (2019, March 13). Variable Interest Entities in China, GMT Research Guest Series, 1-2, https://www.chinaaccountingblog.com/weblog/2019-03-vie-gillis.pdf [Accessed 31.10.2020].

Guo, L. (2014). Chinese Style VIEs: Continuing to Sneak under Smog? Cornell International Law Journal, 47(3), pp. 569-606.

Hong Kong Exchanges and Clearing Limited (2020). List of $H$ Share Companies, https://www.hkex.com.hk/Market-Data/Statistics/Consolidated-Reports/China-Dimension?sc_lang=en\&tabName=GEM [Accessed 31.10.2020].

Larson, M. (2019). Alibaba's VIE structure and erosion of beps goals in China's e-commerce industry. Temple INT'L \& Comp. L.J. 33(1), pp. 204-243.

Latham \& Waltkins (2019). China Introduces New Foreign Investment Law, Negative Lists, and Encouraged Industries Catalogue. Client Alert White Paper No. 2531, pp. 1-9, https://www.lw.com/thoughtLeadership/china-introduces-new-foreign-investment-law-negative-lists-and-encouraged-industries-catalogue [Accessed 31.10.2020].

Lee, R.T. (2011). Understanding the VIE Structure: Necessary elements for success and the legal risks involved. Cadwalader Wickersham \& Taft LLP, https://www.lexology.com/library/detail.aspx?g=aa820b96-ff4a-4704-b457-243dce432a81 [Accessed 31.10.2020].

Liu, C. (2018). Chinese offshore IPOs grow more reliant on shaky legal structure. Nikkei Asian Review, https://asia.nikkei.com/Business/Markets/Chinese-offshore-IPOs-grow-more-relianton-shaky-legal-structure [Accessed 31.10.2020].

London Stock Exchange (2020). AIM Issuers by country of operation, https://www.londonstockexchange.com/reports?tab=aim [Accessed 31.10.2020].

London Stock Exchange (2020). Issuer list, https://www.londonstock exchange.com/reports?tab=issuers [Accessed 31.10.2020].

Powell, J. (19.10.2019). China VIEs: the scale of exposure. Financial Times, https://ftalphaville.ft.com/2019/10/10/1570714343000/China-VIEs--the-scale-of-exposure/.

Schindelheim, D. (2012). Variable interest entity structures in the people's republic of china: Is uncertainty for foreign investors part of china's economic development plan. Cardozo Journal of International and Comparative Law, 21(1), pp. 195-234.

Shen, W. (2012). Deconstructing the myth of Alipay Drama-Repoliticizing foreign investment in the telecommunications sector in China. Telecommunications Policy, 36, pp. 929-942.

Shi, S.Y. (2014). Dragon's house of cards: Perils of investing in variable interest entities domiciled in the people's republic of china and listed in the united states. Fordham International Law Journal, 37(4), pp. 1265-1308.

U.S.-China Economic and Security Review Commission. (2020). Chinese Companies Listed on Major U.S. Stock Exchanges. U.S. Government Publishing Office, https://www.uscc.gov/research/Chinese-companies-listed-major-us-stock-exchanges [Accessed 02.10.2020].

Whitehill, B. (2017). Chinese Companies and the VIE Structure. Council of Institutional Investors, https://www.cii.org/files/publications/misc/12_07_17\%20Chinese\%20Companies\%20and\%20the\%20VIE\%20Structure.pdf [Accessed 01.10.2020]. 